\title{
Human Resource Practices as an Amplifier for Managerial Emotional Intelligence to Boost Employee Performance
}

\author{
Hina ZAHOOR ${ }^{*}$, Nasir MUSTAFA ${ }^{* *}$
}

\begin{abstract}
Aim: Human Resource (HR) practices improve managerial emotional intelligence (EI) and have a great impact on the efficiency and performance of an organization which is the outcome of employee performance, innovation and employee relation. The objective of the present study is to seek out the association between HR practices i.e. Selection \& promotion and Training with EI and also to find out the effects of managerial EI on Employee performance.

Method: A convenient sampling technique is used in the study and three Hypotheses are formulated and tested with different statistical tools. The instrument used to conduct quantitative research is a questionnaire in the study which was filled by HR managers of secondary health care units. The collected data was then analyzed by using relevant descriptive statistics, mean, correlations and simple linear regressions, using IBM SPSS21 and ANOVA (Analysis of variance).

Results: Results demonstrate the positive relationship between Selection \& Promotion with managerial employee intelligence, training \& development with managerial employee intelligence and managerial employee intelligence with employee performance.

Conclusion: The present study result shows that Human resource practices i.e. Selection \& Promotion and training \& development have a positive relation with managerial emotional intelligence which directly impacts employees' performance so it is conducive for secondary health care units firstly to invest more money in training sessions.
\end{abstract}

\footnotetext{
Özgün Araştırma Makalesi (Original Research Article)

Geliş / Received: 16.10.2020 \& Kabul / Accepted: 31.03.2021

DOI: https://doi.org/10.38079/igusabder.811555

* Lecturer, Istanbul Gelisim University, Istanbul, Turkey, E-mail: hzahoor@gelisim.edu.tr ORCID https://orcid.org/o000-0003-2322-5678

** Assist. Prof. Dr., Istanbul Gelisim University, Istanbul, Turkey,

E-mail: nmustafa@gelisim.edu.tr ORCID https://orcid.org/o000-0002-5821-9297
} 
Keywords: Selection \& Promotion, training and development, managerial employee intelligence, employee performance, emotional intelligence theory.

\section{Çalışan Performansını Artırmaya Yönelik Yönetsel Duygusal Zekâ İçin Bir Güçlendirici Olarak İnsan Kaynakları Uygulamaları}

$\ddot{0} \mathbf{z}$

Amaç: İnsan Kaynakları (İK) uygulamaları yönetsel duygusal zekâyı (EI) geliştirir ve çalışan performansı, yenilikçilik ve çalışan ilişkisinin sonucu olan organizasyonun verimliliği ve performansı üzerinde büyük etkiye sahiptir. Bu çalışmanın amacı, İK uygulamaları, yani Seçim ve terfi ve Duygusal Zekâ (EI) ile Eğitim arasındaki ilişkiyi araştırmak ve ayrıca yönetsel EI'nin Çalışan performansı üzerindeki etkilerini ortaya çıkarmaktır.

Yöntem: Çalışmada uygun örnekleme tekniği kullanılmış ve üç Hipotez formüle edilmiş ve farklı istatistiksel araçlarla test edilmiştir. İkinci basamak sağlık birimlerinin İK yöneticileriyle yapılan çalışmada nicel araştırma yapmak için anket ile veri toplanmıştır. Toplanan veriler daha sonra ilgili tanımlayıcı istatistikler, ortalama, korelasyonlar ve basit doğrusal regresyonlar kullanılarak IBM SPSS21 ve ANOVA (Varyans Analizi) kullanılarak analiz edildi.

Bulgular: Sonuçlar, yönetsel çalışan zekâsı ile seçim ve terfi, yönetsel çalışan zekâsı ile eğitim ve geliştirme ve çalışan performansı ile yönetsel çalışan zekâsı arasındaki pozitif ilişkiyi göstermektedir.

Sonuç: Mevcut çalışma sonucu, İnsan kaynakları uygulamalarının, yani Seçim ve Terfi ve eğitim ve geliştirmenin, çalışanların performansını doğrudan etkileyen yönetsel duygusal zekâ ile pozitif bir ilişkisi olduğunu ve bu nedenle, ikincil sağlık hizmetleri birimlerinin öncelikle eğitim oturumlarına daha fazla para yatırmasına elverişli olduğunu göstermektedir.

Anahtar Kelimeler: Seçim ve terfi, eğitim ve geliştirme, yönetsel çalışan zekâsı, çalışan performansı, duygusal zekâ teorisi.

\section{Introduction}

Most exigent issues in the health care unit akin with staff's behavioral and cognitive issues, failure to influence others by their actions in terms of misinterpretation of a word and many psychological scientists consider emotions as the key driver for substantial decisions as explained in different studies ${ }^{1-3}$. Emotions are the fundamental part of human nature which influence managerial decisions, interpersonal communication, and also job performance and are pertinent to the work of managers; So for the giving 
challenges of the managerial job, emotional intelligence is suggested as therapy ${ }^{4}$. Emotional intelligence as per definition is the collection of processes which help to recognize and manage one's own and others' emotions and these feelings are also the source of motivation and achievement 5 . Emotional intelligence is also considered one of the important management issues as it helps to control or minimize the exposure to negative emotions and if the employees are unable to manipulate these it might cause a negative impact on their job performance and satisfaction ${ }^{6}$. Furthermore, Organizational practices and policies help managers to learn EI skills and Human resource management plays important role in shaping managerial behavior to deal with situations that directly relate with emotions7. According to a research study, HR practices have an impact on organizational performance and this organizational performance is the result of employee performance, innovation and employment relation ${ }^{8}$. Many studies show a positive relation between Emotional Intelligence and worker Performance but there is very limited literature in the health care sector ${ }^{9}$

The present study contributes to the literature by providing knowledge of how existing HR practices shape up managerial emotional intelligence. So far studies have emphasized on impact of EI training program but on the contrary, this research posits that other organizational practices like selection and promotion affect managerial emotional skills and also provides knowledge on the Managerial emotional intelligence assessment. This research is aimed to identify the relationship between HR practices (Selection \& promotion and Training \& Development) and the emotional skills of managers and the relation between managerial emotional skills to Employee performance in the public health sector in Pakistan.

\section{Problem Statement}

Many pieces of research gauge EI competencies among managers in the nongovernmental sector ${ }^{10}$. Despite ample evidence from the business sector, few have been published in Public services and especially within the context of the health sector. As there is limited literature on emotional intelligence in the health sector and if available the sample size is small and so researchers also recommended for further research in this area of the service sector ${ }^{11}$. Moreover, studies also reveal that emotional context is the major part of the organization but to the best of our knowledge no previous theoretical framework addresses the relation of HR practices to influence in managerial EI in the 
health care sector ${ }^{12}$. Although, previous researches have been focused Emotional intelligence of leaders within the context of job performance, job satisfaction and motivation of employees and also on the importance of managerial EI and each individual factors which is related to it, but the influence of HR practices on managerial EI and its impact on employee performance in health care units has not been previously considered so the present study aims to fill this gap ${ }^{13-15}$.

This study is conducted to explore the significant relationship between HR practices, perceived emotional skills of managers and Employee performance in the health care sector. It is based on a survey of HR managers in hospitals in Pakistan, Karachi.

\section{Emotional Intelligence Theory}

The theory of emotional intelligence depicts that EI depends on a leader's social awareness, self-awareness, social skills and self-management. It is directly associated with each other. He also pointed out that the effectiveness of personal and organizational value-based on EI. He emphasized that EI should be the benchmark for promotion and succession planning, especially for a leadership position. He also considered EI as vital in terms of training and development and selection? 9

A research study found a broad range of EI skills (developing others, influence, selfconfidence) and a narrow range of cognitive skills (Analytical thinking approach), distinguishing high achiever to the average performer while reviewing the data from executive positions of different professions of more than 30 different organizations ${ }^{16}$.

Researchers define Emotional intelligence differently but most of them agree that it is a concept that involves a wide range of behaviors and skills. Salovey and Mayer defined it as "relevant to the accurate appraisal and expression of emotion in self and others, and the feeling to motivate, plan and achieve in one's life ${ }^{17}$. 
Figure 1 Salovey and Mayer's EI model ${ }^{17}$

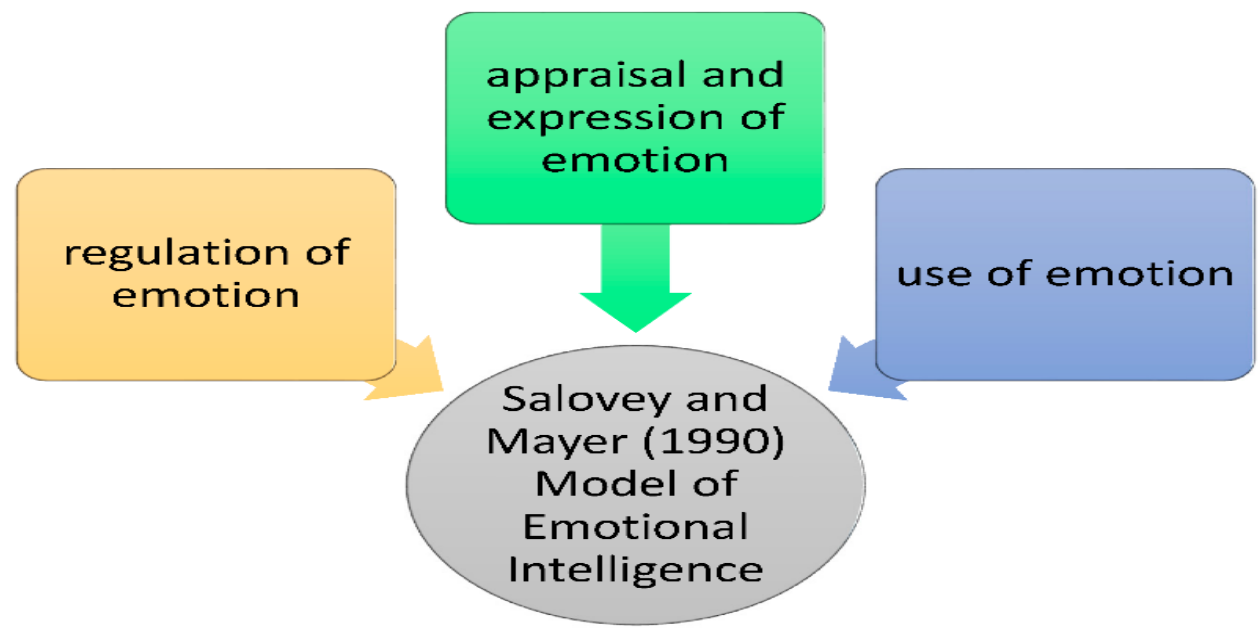

According to Goleman (2002), EI is the combination of elements; self-awareness and management, social awareness and skills9.

Figure 2 Mixed Model of Emotional Intelligence by Daniel Goleman ${ }^{9}$

\section{Emotional Intelligence}

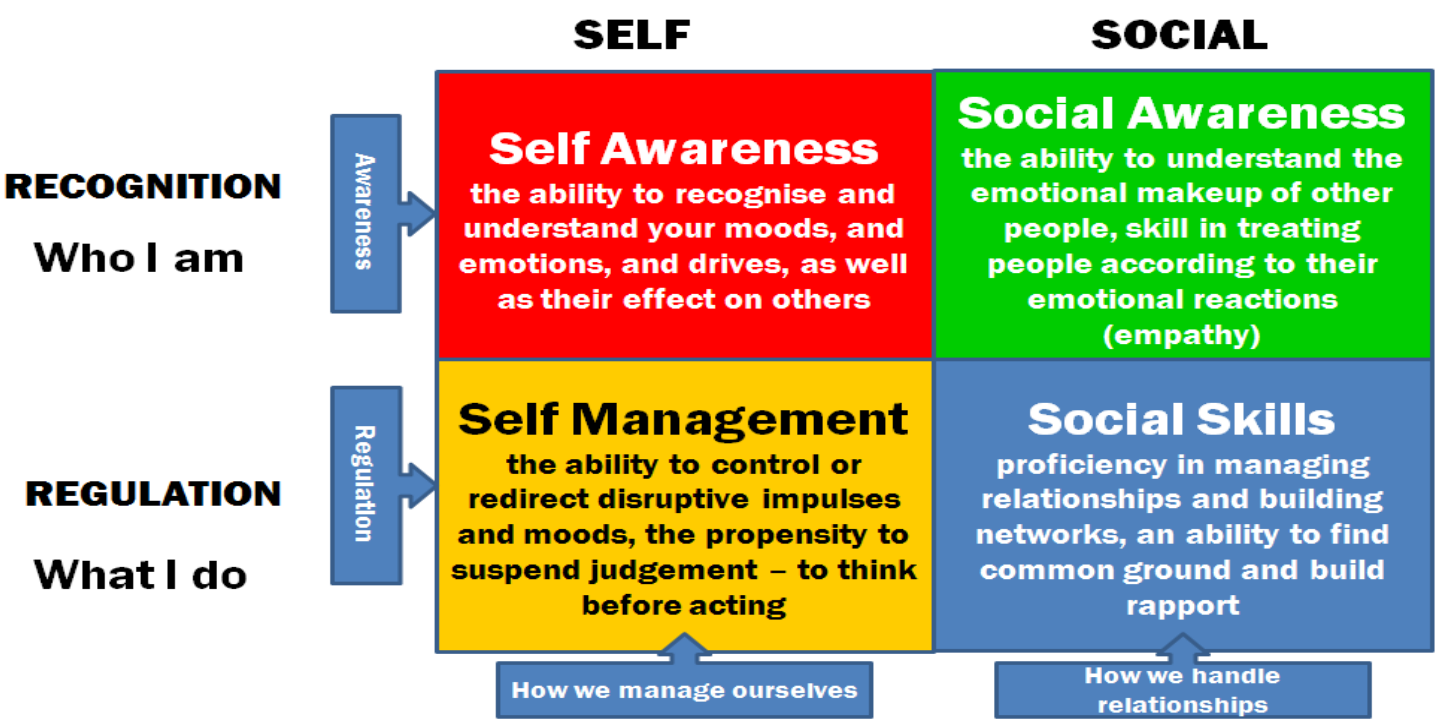


Self-awareness means knowledge and understanding of one's emotions. It's also a source of feedback and to know their weaknesses and strengths and ultimately it is linked with one's own confidence ${ }^{18}$.

Self-management is the combination of emotional self-control, pellucidity, initiative, adaptability, accomplishment, transparency and optimism. It is the tendency to evaluate disruptive emotions and be adaptable and instead of rigid be flexible in one's own response ${ }^{19}$.

Social awareness is stated as one's skill to identify others' needs and emotions and also to address their needs. It is not just on the interpersonal level but at the organizational level as top performers share their skills among managers and executive level. Social awareness enables leaders to be more effective in responding because they watch the situation objectively free from biasness 9 .

Relationship management is another artifact of emotional intelligence and it is the skill to manage successful interactions by understanding your own and others' emotions. According to research scholar, it is the bond of admiration and support and this ability also promotes teamwork activities by managing conflicts?

These social skills are basically the association between leadership and EI. It is the ability of a leader to resolve team's conflicts and to motivate and inspire them to follow him?. Considering its vital feature for productivity, approximately fortune 1000 companies trained their $40 \%$ of employees for leadership skill by special training sessions between 1990 to $1999^{20}$. Research study highlighted that the Soft skills demand of workers has rapidly increased due to employers' interest to look for less educated and entry-level workers $^{21}$. 


\section{Theoretical Framework}
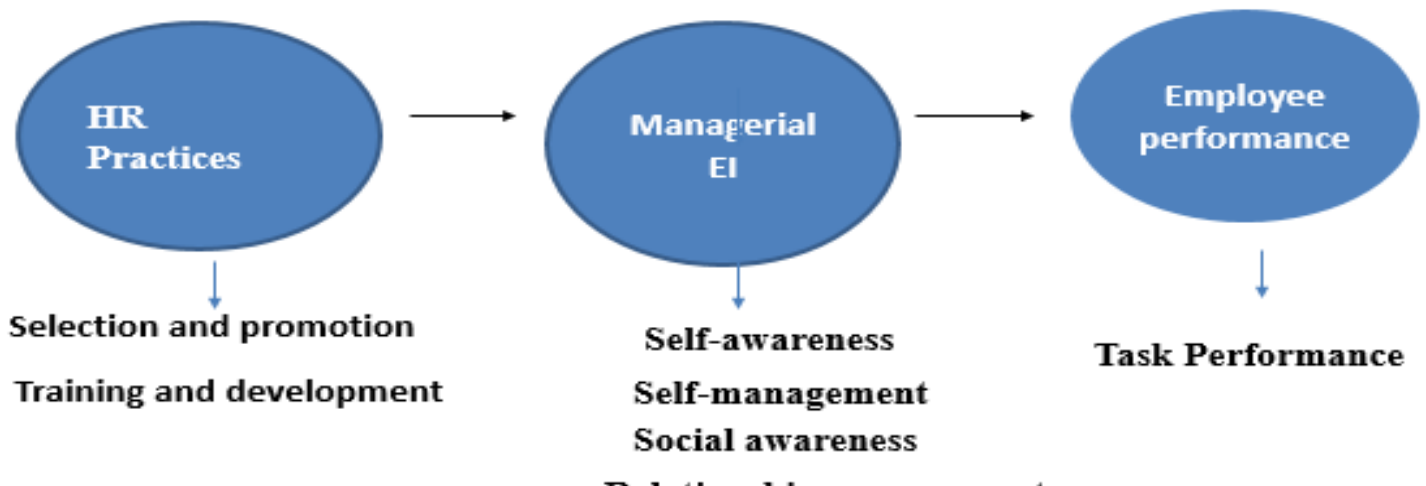

Task Performance

Relationship management

\section{HR Practices and Managerial Emotional intelligence}

\section{Selection and promotion \& Managerial EI.}

Selection of a competent person for the job is often a difficult task ${ }^{22}$. Selection processes can identify people's skills by investigating candidates' self-knowledge and emotional understanding and can evaluate through queries ${ }^{23,24}$. The organization thought that selection is the criteria for the improvement of managerial EI as it helps to attain detailed information about people skills by assessing their self-knowledge and EI and also by inquiring about their EI approach under demanding circumstances7. Furthermore, the research study also emphasized on the interview of present and former supervisors and coworkers with respect to these aspects of candidates as the selection process aid in assessing candidate knowledge and emotional intelligence in terms of identifying self and others emotions ${ }^{25}$. Hence the hypothesis is formulated as:

H1: Selection and promotion (self-knowledge \& people skill) processes increases Managerial EI.

\section{Training and Development \& Managerial EI}

Training \& development is considered as a crux to raise organizations productivity. Previous studies also revealed that training and development have a positive relationship with employee performance and also with motivation in the health sector ${ }^{26}$. Training is 
the way to develop managerial and leadership competencies. According to research scholars, a wide range of training programs are being offered that aim Emotional intelligence ${ }^{27}$. While other available training sessions. i.e. change management, teamwork also links with Emotional intelligence skills7. Research scholars explored in their study that managers got high score on typical emotional intelligence and an increase in work morale and a decrease in distress after training as compared to the control group ${ }^{28}$. In addition, other studies also found similar results with raised EI when compared with nonrandom and random assigned groups ${ }^{29,30}$. Thus following hypothesis is formulated:

H2: Training relates to people skills increases Managerial EI.

\section{Managerial EI \& Employee Performance}

Research study reveals that Human Resource practices impact on organizational performance and the important implications of organizational performance are market performance and productivity performance ${ }^{31}$. Many studies highlight the impact of Emotional intelligence on Performance of employee and emphasize on developing the interpersonal skills of employees for better job performance ${ }^{32}$. Researchers also agreed on the assertion that emotional intelligence is an important factor for an organization as it develops the interpersonal skills in team member too. Moreover, an individual with high EI behaves more empathically which enables him to be more motivated to deal with working conditions and to sponge up job stress ${ }^{33}$. Hence the following hypothesis formulated:

\section{H3: Managerial EI affects EP}

\section{Material \& Methods}

\section{Population and Sample}

According to the Health department government of Sindh, the number of health facilities are 90 Secondary units (DHQ-14 Hospitals, THQ-49 Hospitals, Major/Other/Speclizied27 Hospitals). The target population of this study is HR managers in secondary health care units of Karachi, Pakistani hospitals. This population is selected for two reasons; firstly, HR managers have influential positions and they are well informed about managerial activities7 ${ }^{7}$ Secondly, Further research is recommended in the health sector 
by the researcher in the context of $\mathrm{EI}^{11}$. Primary data is used in the research. A Convenient Sampling technique is used for this study.

\section{Instrument}

For the present study quantitative data is collected through an adopted Questionnaire from secondary units of Karachi, Pakistan. The questionnaire consists of close-ended questions with the use of 5 points Likert scale. All questionnaires were distributed and collected by hand to 15 hospitals.

The questionnaire has 4 sections.

Section A. is based on HR Practices.

1. Selection and promotion Promote EI.

2. Training and Development to Promote Emotional Intelligence.

Section B is based on Perceptions related to Emotional Intelligence

Section $\mathbf{C}$ is based on Employee performance in terms of Task Performance

\section{Results}

Reliability is measured by Cronbach's Alpha in the present study. Summarized results are presented in Table 1.

Table 1: Reliability Analysis

\begin{tabular}{|l|l|l|l|}
\hline S.NO & Variables & Cronbach's Alpha & Items \\
\hline $\mathbf{1}$ & Selection and promotion & .642 & 8 \\
$\mathbf{2}$ & Training and development & .648 & 12 \\
\hline $\mathbf{3}$ & Managerial EI & .892 & 20 \\
\hline $\mathbf{4}$ & Employee Performance & .875 & 21 \\
\hline
\end{tabular}

Table 1, above shows the reliability of HR practices $(\alpha=0.642)$ followed by Training and development ( $\alpha=0.648)$, Managerial EI ( $\alpha=0.892)$, Employee Performance $(\alpha=0.875)$. As stated in Uma sekaran, 4th Edition, the higher consistency reliability depends on how Cronbach's alpha is close to 1 . Here all the values of Cronbach's alpha are higher than 
0.821 therefore, it can be safely assumed that the variables used in the present study have a good level of internal consistency.

The results of Table-2, shows the correlation between Selection \&Promotion with Emotional Intelligence the correlation was as high as $(\mathrm{R}=0.515)$, the correlation between Training \& Development with Employee Performance the correlation was as high as $(\mathrm{R}=0.515)$, and Correlation of with Emotional Intelligence is as low as $(\mathrm{R}=0.531)$.

Table 2: Correlations

\begin{tabular}{|c|c|c|c|c|}
\hline & SP & TD & EI & EP \\
\hline \multirow{3}{*}{ SP } & 1 & .515 & $.515^{* * * *}$ & $.531^{* * * *}$ \\
\hline & & & 0 & 000 \\
\hline & 250 & 250 & 250 & 250 \\
\hline \multirow{3}{*}{ TD } & $.515^{* * *}$ & 1 & $.515^{* * * *}$ & $.794^{* * * *}$ \\
\hline & 000 & & 000 & 000 \\
\hline & 250 & 250 & 250 & 250 \\
\hline \multirow[t]{3}{*}{ EI } & $.515^{* *}$ & $.515^{* * *}$ & 1 & $.794^{* * *}$ \\
\hline & $\mathrm{OOO}$ & 000 & & 000 \\
\hline & 250 & 250 & 250 & 250 \\
\hline \multirow{3}{*}{ EP } & $.531^{* * *}$ & $.531^{* *}$ & $.794^{* * *}$ & 1 \\
\hline & 000 & 000 & 000 & \\
\hline & 250 & 250 & 250 & 250 \\
\hline
\end{tabular}

*** Correlation is significant at the 0.01 level (2-tailed).

\section{Hypotheses testing:}

a) Hypothesis 1 :

\section{Selection \& Promotion correlation with Managerial Employee intelligence.}

The values of $t=4.202$ and $\operatorname{sig}=.000$ shows that null hypothesis is rejected, therefore it reveals a positive relationship exists.

b) Hypothesis 2

\section{Training \& Development correlation with Managerial Employee intelligence.}


The values of $\mathrm{t}=4.102$ and $\mathrm{sig}=.000$ shows that null hypothesis is rejected, therefore it reveals a positive relationship exists.

c) Hypothesis 3:

\section{Managerial Employee intelligence correlation with Employee Performance}

The values of $t=4.39$ and $\operatorname{sig}=.000$ shows that null hypothesis is rejected, therefore it reveals a positive relationship exists.

\section{Discussion}

Organizations in the contemporary society spend much on training programs to train their workers to provide better quality services to their customers not only just focus on profit-making Training benefits the employee by developing employee skills and knowledge and it also improves managerial skills to become more acquainted to their own and others feelings and also helps them to better understand their own weaknesses and strength which leads to improve relationship and communication skills. Other HR practices like selection also help to improve Managerial EI by getting detailed knowledge of candidate's skills and emotional literacy in trying circumstances.

The present study examined the relation of HR practices i.e selection \& promotion and training with managerial emotional intelligence and Employee Performance. A deductive approach is used for a quantitative study. Questionnaires were filled by HR managers of secondary health care units of Karachi, Pakistan. Results demonstrate the positive relationship between Selection \& Promotion, Training \& Development with Managerial Employee intelligence and also a positive relationship between Managerial Employee intelligence with Employee Performance. All three hypotheses are accepted. The present research suggests that HR professionals can improve EI skills in health units by accentuating Emotional intelligence abilities in their practices with selection \& Promotion and training. HR practitioners can highly aid in this process for developing EI skills. According to a research study, HR managers are responsible to maintain employee's engagement by providing a good working environment ${ }^{6}$.

\section{Conclusion}

The present study result shows that Human resource practices i.e. Selection \& Promotion and training \& development have a positive relation with managerial emotional 
intelligence which directly impacts employees' performance so it is conducive for secondary health care units firstly to invest more money in training sessions and organize effective training programs for managers to improve managerial performance, skills, and knowledge to understand, as stated in the study that individuals with emotional intelligence have the characteristic of Empathy in their actions so they respond more properly due to accuracy in his verbal and nonverbal competencies for social functioning33. Secondly, there is a need to focus on other HR practices i.e selection process in health care units, cause selection process aid in assessing candidate's knowledge and emotional intelligence in terms of identifying self and others' emotions.

This research is limited to HR managers of health care units in Karachi, Pakistan. In future research HR managers of tertiary health care units could be used as a sample and also comparative study between two health care systems of different countries including the senior managerial level of the health sector could be conducted to explore their performance and emotional intelligence in their respective areas of the health sector.

\section{REFERENCES}

1. Gilbert P. Gilbert Evolution and depression: issues and implications. Psychological Medicine.2006;36:287-297.

2. Lowenstein A, Katz R, Prilutzky D, Mehlhausen-Hassoen D. The intergenerational solidarity paradigm. In: Daatland SO, Herlofson K, eds. Ageing, intergenerational relations, care systems and quality of life. Oslo: Norwegian Social Research;2001.

3. D Keltner, A Kogan, PK Piff. The sociocultural appraisals, values, and emotions (SAVE) framework of prosociality: Core processes from gene to meme. Annual review of Psychology. 2014;65:425-460.

4. Nurachadijat K, Hadhienata S, Sunaryo W. Analysis of sequential explanatory of teacher's performance reviewed from transformational leadership, job engagement, and interpersonal communication. International Journal of Managerial Studies and Research. 2017;5(9):24-29. doi:10.20431/23490349.0209005. 
5. Salovey P, Mayer JD. Emotional intelligence. Imagination, Cognition and Personality. 1990;9(3):185-211. doi:10.2190/dugg-p24e-52wk-6cdg.

6. Brunetto Y, Teo ST, Shacklock K, Farr-Wharton R. Emotional intelligence, job satisfaction, well-being and engagement: Explaining organizational commitment and turnover intentions in policing. Human Resource Management Journal. 2012;22(4):428-441. doi:10.1111/j.17488583.2012.00198.x.

7. Ettington DR. How human resource practices can help plateaued managers succeed. Human Resource Management. 1998;36(2):221-234. doi:10.1002/(sici)1099-050x(199722)36:2<221::aid-hrm4>3.o.co;2-z.

8. Guest DE. The psychology of the employment relationship: An analysis based on the psychological contract. Applied Psychology. 2004;53(4):541-555. doi:10.1111/j.1464-0597.2004.00187.x.

9. Goleman D, Bayatzis R, Mckkee A. Primal Leadership: Realizing the Power of EI. Boston: Harvard Business School Press; MA,2002.

10. Druskat VU. Scholarship that works. Academy of Management Journal. 2005;48(6):952-955. doi:10.5465/amj.2005.19573094.

11. Ayiro PL, Sang KJ. Emotional intelligence and leadership - A case for quality assurance managers in Kenyan universities. In: Emotional Intelligence - New Perspectives and Applications;2012:Chapter 6. doi:10.5772/30999.

12. Radhakrishnan A, Udayasuriyan G. Emotional intelligence and its relationship with leadership practices. International Journal of Business and Management. 2010;5(2):65-76. doi:10.5539/ijbm.v5n2p65.

13. Alston BA, Dastoor BR, Sosa-Fey J. Emotional intelligence and leadership: a study of human resource managers. International Journal of Business and Public Administration. 2010;7(2):61-75.

14. De Haro JM, Castejon JL, Gilar R. Personality and salary at early career: The mediating effect of emotional intelligence. The International Journal of Human Resource Management. 2018;31(14):1844-1862. 
doi:10.1080/09585192.2017.1423365.

15. Jamali D, Sidani Y, Abu-Zaki D. Emotional intelligence and management development implications. Journal of Management Development. 2008;27(3):348-36o. doi:10.1108/02621710810858641.

16. McClelland DC. Identifying competencies with behavioral-event interviews. Psychological Science. 1998;9(5):331-339. doi:10.1111/1467-9280.00065.

17. Mayer JD, Caruso DR, Salovey P. Emotional intelligence meets traditional standards for an intelligence. Intelligence. 1999;27(4):267298. doi:10.1016/so16o-2896(99)ooo16-1.

18. Channer P, Hope T. The emotionally intelligent leader. Emotional Impact. 2001;25-26. doi:10.1057/9780230508842_5.

19. Dearborn K. Studies in emotional intelligence redefine our approach to leadership development. Public Personnel Management. 2002;31(4):523-530. doi:10.1177/009102600203100408.

20. Kuhn P, Weinberger C. Leadership skills and wages. Journal of Labor Economics. 2005;23(3):395-436. doi:10.1086/430282.

21. Fasenfest D, Moss P, Tilly C. Stories employers tell: Race, skill, and hiring in America. Contemporary Sociology. 2002;31(5):512. doi:10.2307/3090018.

22. Sowa JE, Word JK. Introduction. The Nonprofit Human Resource Management Handbook. 2017.

23. Higgs M, Aitken P. An exploration of the relationship between emotional intelligence and leadership potential. Journal of Managerial Psychology. 2003;18(8):814-823. doi:10.1108/02683940310511890.

24. Wong C, Law KS. The effects of leader and follower emotional intelligence on performance and attitude: An exploratory study. Leadership Perspectives. 2017:97-128. doi:10.4324/9781315250601-10.

25. Ilgen DR, Pulakos ED. The changing nature of performance: Implications for staffing, motivation, and development. San Francisco:1999. 
26. Zahoor H, Ghulam M. Impact of training and development on nurses and technical staff's performance and motivation, A case study of Shamsi hospital Karachi. InTraders International Trade Congress Book. 2019.

27. Caudron S. The hard case for soft skills. Workforce. 1999;78(7):60-6.

28. Slaski M, Cartwright S. Emotional intelligence training and its implications for stress, health, and performance. Stress and Health. 2003;19:233-239.

29. Schutte NS, Malouff JM, Hall LE, et al. Development and validation of a measure of emotional intelligence. Personality and Individual Differences. 1998;25(2):167-177. doi:10.1016/s0191-8869(98)oooo1-4.

30. Groves KS, McEnrue MP, Shen W. Developing and measuring the emotional intelligence of leaders. Journal of Management Development. 2008;27:225250.

31. Becker BE, Huselid MA, Pickus PS, Spratt MF. HR as a source of shareholder value: Research and recommendations. Human Resource Management. 1997;36(1):39-47.

32. Bar-On R. Emotional quotient-inventory. PsycTESTS Dataset. 2012. doi:10.1037/to4985-00o

33. Zahoor H, Ghulam M, Mustafa N. Emotional intelligence is the Beta Blocker for job stress. A comparative study of academicians of Pakistan and Turkey. InTraders Uluslararası Ticaret Dergisi. 2019;2(2):205-223. 